\title{
NARASI SIMBOLIK RELIEF "MANUSIA INDONESIA" KARYA SUDJOJONO DI EKS BANDARA KEMAYORAN, JAKARTA PUSAT
}

\author{
Oleh: Julia Dwi Yanti \\ Institut Seni Indonesia Yogyakarta
}

\begin{abstract}
ABSTRAK
Relief 'Manusia Indonesia' karya Sudjojono merupakan salah satu relief beton pertama di Indonesia yang dibuat atas prakarsa Bung Karno pada zaman prakemerdekaan Indonesia. Tema dan ide relief 'Manusia Indonesia' tersebut dirancang oleh S. Sudjojono pada dinding ruang tunggu VIP di Bandara pertama Indonesia, Bandara Kemayoran, Jakarta Pusat. Hakikat seni dalam pemikiran Sudjojono dengan konsep jiwa ketok pun Sudjojono tuangkan pada sebuah relief yang diberi judul "Manusia Indonesia" pada tahun 1957.

Narasi simbolik yang ada pada relief 'Manusia Indonesia' karya Sudjojono ini menceritakan tentang kearifan lokal dan kekayaan alam bangsa Indonesia. Melalui observasi dan pengamatan yang mendalam, ditemukan beberapa fakta bahwasanya Sudjojono ingin merepresentasikan jati diri bangsa Indonesia di mata dunia melalui figur-figur maupun simbol yang ada di dalam rangkaian relief beton tersebut. Kearifan lokal pada relief tersebut ditandai dengan beberapa simbol yang mewakili pakaian adat masyarakat Indonesia kala itu, budaya, flora, maupun fauna yang ada. Kekayaan alam Indonesia juga digambarkan dengan ilustrasi aktivitas penambangan dan wilayah maritime Indonesia. Seiring berjalannya waktu, bandara yang dahulunya pernah menjadi salah satu kebanggaan bangsa Indonesia ini, kini sudah beralih fungsi menjadi sebuah bangunan tua yang tidak terurus lagi. Begitu pun dengan relief-relief yang ada di dalamnya.
\end{abstract}

Kata kunci: Sudjojono, relief, bandara kemayoran, narasi, simbolik.

\begin{abstract}
Sudjojono's Relief of 'Manusia Indonesia' is one of the first concrete reliefs in Indonesia that was ordered by Bung Karno in pre-independence era of Indonesia. The theme and idea of 'Manusia Indonesia' designed by S. Sudjojono in 1957 was located in VIP lounge wall at Indonesia's first airport, Kemayoran Airport, Central Jakarta. The relief design has shown Sudjojono's concept of "jiwa ketok".

This research observed the symbolic narration found in Sudjojono's relief of 'Manusia Indonesia'. Through deep observation and examination, there are some facts that Sudjojono aimed to represent Indonesia's identity in the eyes of the world through the figures and symbols that exist in the series of concrete reliefs. The narration of the relief has shown the local wisdom and the natural wealth of Indonesia. Local wisdom on the relief was marked by several symbols representing the customary clothing of Indonesian society at that time, culture, flora, and fauna that exist. Indonesia's natural wealth was also captured by the illustration of mining activities and the maritime territory of Indonesia. Over time, the airport that once was one of the pride of Indonesia, has now turned the function into an old building that is now neglected. So is the reliefs in it.
\end{abstract}

Keywords: Sudjojono, relief, Kemayoran Airport, Narration, symbolic. 


\section{PENDAHULUAN}

\section{A. Latar Belakang Penelitian}

Sebelum merdeka, negara Indonesia telah merasakan masa-masa getir dijajah oleh beberapa negara asing. Kota Jakarta (Batavia) misalnya, yang merupakan salah satu kota tua di Indonesia dengan banyak kampung tua yang menyimpan sejarah panjang perjuangan bangsa Indonesia dalam masa-masa pra kemerdekaan maupun pasca kemerdekaan di Indonesia.

Nama dari kampung-kampung tua itu kebanyakan memiliki asal muasal, salah satunya adalah Kemayoran. Sesaat setelah bandar udara Kemayoran dibangun sekitar tahun 1934, wilayah Kemayoran semakin banyak didatangi oleh para pendatang, baik yang berasal dari Belanda maupun dari nusantara. Hal tersebut disebabkan karena pembangunan yang dikerjakan pada masa pemerintahan kolonial Belanda. Berdasarkan cerita masyarakat sekitar dan beberapa artikel yang pernah penulis baca, Kemayoran kemudian dikenal dengan julukan "Belanda Kemayoran" karena banyak dihuni oleh orang Indo-Belanda.

Tak dapat disangka bahwasanya di kampung Kemayoran ini, terdapat bandar udara pertama yang dibangun di Indonesia. Sejarah panjang juga mengungkap bahwa didalam gedung ini terdapat sebuah karya seni yang dahulunya menjadi kebanggaan bagi bangsa ini. Terdapat tiga relief yang tersimpan seakan bercerita tentang legenda maupun kebiasaan yang dilakukan oleh masyarakat Indonesia. Karya relief tersebut ialah hasil dari tangan-tangan seniman Harijadi, Surono, dan Sudjojono.

Kini relief tersebut seperti terabaikan oleh bangsanya sendiri. Tidak terawat dan beberapa bagiannya bahkan ada yang hilang. Sisi keindahan relief juga memudar karena kerusakan diberbagai tempat pada dinding relief.

“... ketika karya seni apapun diamati secara mendalam, ia akan terlihat 'berbeda', menampak sebagai ruang virtual atau menjadi subjek yang maknanya berpijar menjadi apa-apa. Melalui pengamatan mendalam karya seni yang tadinya biasa-biasa saja, akan menjadi luar biasa atau jadi absurd, yang tadinya berkesan luar biasa menjadi biasa-biasa saja, karena pemaknaan atasnya bergeser dari sebelumnya. Inilah yang dimaksud dengan frase "Ajaibnya Pengamatan". (M. Dwi Marianto; 2015, hal. vi). 
Tertarik dengan pembahasan mengenai pengamatan seni yang mendalam, sehingga dapat memvirtualisasikan sebuah keberadaan seni itu sendiri, penulis mencoba untuk menggali karya seni yang dapat diistilahkan: "ada tetapi tak ditampakkan". Berawal dari presentasi mengenai pembuatan film dokumentasi oleh IVVA- Indonesian Visual Art Archive mengenai karya seni berupa relief yang berada didalam sebuah bangunan bekas bandar udara bertaraf internasional pertama di Indonesia yang pernah diputar di gedung audio visual jurusan seni murni Fakultas Seni Rupa ISI Yogyakarta.

Pembahasan mengenai eks Bandara Kemayoran dan relief yang pernah menjadi ikon daya tarik pengunjung baik itu domestik ataupun non-domestik pada zaman pra kemerdekaan dan beberapa tahun pasca kemerdekaan juga tak bisa terbantah menjadi sejarah bagi sejarah bangsa Indonesia khususnya pada dunia penerbangan. Dahulu pada zamannya, Bandara Kemayoran ini menjadi bandara pertama yang ada di DKI Jakarta sebelum adanya Bandara Soekarno-Hatta dan Halim Perdana Kusuma. Kini Bandara tersebut sudah beralih fungsi menjadi sebuah bangunan tua yang rapuh dan tak terurus lagi. Begitu pula dengan nasib tiga relief yang dulunya menjadi ikon kebanggaan eks bandara ini.

Pada awal kemerdekaan Republik Indonesia, kontribusi para perupa di dalam perjuangan juga dibuktikan dengan adanya sejumlah poster yang diproduksi pada masa itu. Kebanyakan merupakan poster-poster politik dan propaganda perjuangan. Rasa nasionalis sangat kental terasa ketika melihat berbagai seni yang muncul pada masa menjelang kemerdekaan Indonesia. Situasi politik ketika sejarah panjang menuliskan betapa besarnya pergerakan bangsa dalam mencapai kemerdekaan, membuat tokoh-tokoh Indonesia dekat dan menjalin hubungan akrab dengan seniman-seniman kala itu. Terlebih tokoh besar yang sangat berpengaruh seperti Soekarno, sudah sangat akrab dan sangat tertarik dengan seni. Hal itulah yang menyebabkan para seniman menyatukan pikiran dan ikut berperan andil dalam citacita kemerdekaan bersama tokoh-tokoh yang bersangkutan. Hal ini tercermin dari tujuan organisasi maupun sanggar seni yang muncul serta dari karya mereka.

Setelah perjuangan dalam menggapai kemerdekaan Indonesia tercapai, kondisi sosial dan politik juga masih tak luput dari peran serta seniman dan karya seninya. Berbagai permbicaraan dan diskusi terkait politik dan pemerintahan masih terus disuguhi dengan seni-seni yang ada kala itu. Tema kehidupan perjuangan dan keinginan mendokumentasikannya melalui karya seni banyak ditemukan pada masa 
ini. Salah satunya melalui pembuatan relief di Eks Bandara Kemayoran yang tujuannya adalah sebagai kebanggaan dalam memperlihatkan budaya yang ada pada Bangsa Indonesia. Kegelisahan yang dirasakan penulis adalah ketika melihat sebuah karya yang pernah menjadi ikon dari sebuah kebudayaan Bangsa Indonesia, namun melihat kondisinya yang kini usang dan tidak terawat, seakan membuat penulis merasa tertarik dan ingin menelitinya secara mendalam.

Melalui pengamatan mendalam, suatu objek yang tadinya bukan apa-apa dan sebagai sesuatu yang eksternal dari seorang pengamat, akan menjadi bagian internal dan sekaligus sebagai pengalaman dari pengamat yang bersangkutan. Sehingga ketika si pengamat itu akan dimudahkan ketika ia harus mengatakan atau menuliskan tentang objek bersangkutan melalui bahasa lisan atau dalam bentuk tulisan, sebab objek itu telah berubah menjadi bagian dari pengalaman empiriknya. (M. Dwi marianto; 2015, hal. 77)

Dari berbagai uraian diatas merupakan bentuk penilaian dari sudut pandang objektif maupun subjektif penulis, maka penulis mengambil ide untuk meneliti salah satu relief yang ada di Eks Bandar Udara Kemayoran tersebut. Segala data dan aspek yang diteliti, akan dituangkan melalui penulisan penelitian tugas akhir ini dengan judul "Narasi Simbolik Relief "Manusia Indonesia" Karya Sudjojono di Eks Bandara Kemayoran, Jakarta Pusat.

\section{B. Rumusan Masalah}

Berangkat dari penelitian mengenai Narasi Simbolik Relief "Manusia Indonesia" Karya Sudjojono di eks Bandara Kemayoran, Jakarta Pusat ini, dengan demikian akan mengungkap apa sebenarnya sejarah serta narasi simbolik atas terbentuknya relief di eks Bandara Kemayoran tersebut. Oleh sebab itu, rumusan masalah yang akan diambil adalah:

1. Bagaimana sejarah terciptanya relief "Manusia Indonesia" karya Sudjojono yang terletak di eks Bandara Kemayoran?

2. Sejauh mana relief tersebut merepresentasikan kondisi masyarakat Indonesia kala itu beserta narasi simbolik apa yang telah tercipta dalam relief tersebut?

\section{Teori dan Metode Penelitian}

Teori 
Seni, manusia dan kebudayaan merupakan tiga hal yang saling berkaitan satu sama lainnya. Mengamati sebuah karya seni dapat dilihat dari artefak yang ditemukan dalam studi kasus sebuah penelitian dan pengkajian seni.

Menurut Ernst Cassirer (2015, hal. 6 ) manusia tidak hanya hidup dalam dunia fisik, tetapi hidup dalam dunia simbolis. Bahasa, mite, seni dan agama adalah bagian-bagian dunia simbolis itu. Cassirer juga menegaskan bahwa manusia selain memiliki kemampuan sistem berpikir, juga memiliki kemampuan sistem simbolis. Dengan sistem ini manusia mengembangkan pemikiran simbolis dan perilaku simbolis sebagai ciri khas manusiawi yang berbeda dengan binatang. Hal ini terbukti karena manusia membuat dan menggunakan simbol dalam kehidupannya. Kehidupan budaya manusia dengan kekayaan dan ragamnya adalah bentuk-bentuk simbolis. Perkembangan kebudayaan manusia di dunia ini berkaitan erat dengan kemajuan sistem simbolis manusia.

Pemikiran-pemikiran yang tertuang di dalam sebuah karya seni dapat ditelusuri melalui kehidupan sosial serta budaya yang ada di dalam sebuah kalangan masyarakat.

Manusia sebagai makhluk yang berkebudayaan tidak bisa lepas dengan kehidupan manusia yang lain. Hal ini berarti bahwa manusia dalam mempertahankan hidupnya memerlukan interaksi dengan sesama dan lingkungannya. Interaksi manusia dalam suatu masyarakat akan berkembang menjadi salah satu kebutuhan (sosial), karena setiap manusia senantiasa memerlukan keberadaan manusia yang lain. Dengan demikian, manusia selain sebagai makhluk budaya juga makhluk sosial. Kelompok manusia yang terorganisir dalam suatu masyarakat mengembangkan kemampuan berpikirnya untuk menciptakan kebudayaan. Sehingga kebudayaan yang diciptakan masyarakat sebenarnya akan merupakan sistem pengetahuan dan kepercayaan manusia yang disusun sebagai pedoman manusia dalam mengatur pengalamannya dan persepsi manusia untuk menentukan tindakan dan juga untuk memilih di antara alternatif yang ada. (Ernst Cassirer (2015, hal. 6)

Manusia sebagai makhluk sosial tentunya tidak dapat bertahan hidup apabila hanya seorang diri di dunia. Kehidupan bermasyarakat dijalani manusia setelah menemukan suatu persamaan dalam bersosialisassi untuk mencapai tujuan yang sama.

Aktivitas manusia dalam kehidupan seni merupakan salah satu fakta yang menjadi sorotan sehingga pergerakan seni itu sendiri menjadi dinamis. Adapun 
aktivitas yang dapat dikembangkan sebagai ruang gerak adalah mencipta karya seni, penghayatan, kritik, mengkaji bahkan penelitian seni.

Adapun bagi para akademisi di perguruan tinggi seni, metode menciptakan karya seni ini merupakan segi keilmiahan seni, sehingga setiap mencipta karya seni mereka selalu menggunakan metode. Jadi, karya seni itu tidaklah asal nyeni, seni harus dapat dianalisis secara ilmiah. (Sadjiman Ebdi Sanyoto; 2010, hal. 4-5)

Maka dari itu, diambil kesimpulan bahwa sebuah karya seni dapat diamati melalui unsur-unsur yang ada dalam sebuah karya seni rupa, serta aktivitas seni yang terjadi dalam penciptaan serta penyajian karya seni tersebut.

\section{Metode Penelitian}

Penelitian ini bersifat campuran, artinya akan digunakan metode kualitatif dan kuantitatif secara bersamaan. Hal ini bertujuan karena dalam penelitian ini akan diungkapkan data sejarah dari tahun didirikan hingga kini, namun selain itu juga diharapkan akan mendapatkan data-data yang lebih dalam melalui penelitian kualitatif.

Penelitian fokus tentang jejak sejarah relief "Manusia Indonesia" karya Sudjojono di eks Bandara Kemayoran, Jakarta Pusat. Perlu diketahui kiranya bahasan yang diulas adalah dari sejarah berdirinya Bandara Kemayoran, profil seniman, hingga kondisi karya relief tersebut kini. Kurun waktu yang diambil untuk diteliti dalam penelitian ini adalah dimulai dari berdirinya eks bandara tersebut hingga kini.

Pengumpulan data penelitian membutuhkan suatu instrumen. Instrumen ini dibutuhkan untuk pengambilan data untuk penelitian baik penelitian kualitatif maupun penelitian kuantitatif. Instrumen penelitian adalah alat atau fasilitas yang digunakan oleh peneliti dalam mengumpulkan data agar pekerjaannya lebih mudah dan hasilnya lebih baik dalam arti lebih cermat, lengkap, dan sistematis sehingga lebih mudah diolah.Penulis juga mengkaji secara teoritis referensi serta literatur sejarah lainnya yang berkaitan dengan budaya, nilai dan norma yang berkembang pada situasi sosial yang diteliti. Penulis mengumpulkan data yang diperoleh dari dokumen-dokumen yang ada atau catatan-catatan yang tersimpan, baik berupa buku, surat kabar, dan lain sebagainya. Salah satu dokumentasi video yang telah ada adalah arsip dari IVAA-Indonesian Visual Art Archive- yaitu hasil wawancara dengan salah satu anak dari Sudjojono. 
Data juga didapat melaui wawancara langsung kepada anak pertama Sudjojono, Tedja Bayu Sudjojono. Selain itu juga akan dilakukan pencarian bukti gambargambar, foto maupun video yang mampu memberikan gambaran bentuk serta keadaan karya tersebut di masa-masa sebelumnya.

\section{PEMBAHASAN}

Menelisik mengenai sejarah terbentuknya relief "Manusia Indonesia" karya Sudjojono merupakan suatu hal yang sebenarnya sudah dipikirkan penulis semenjak pertama kali melihat arsip video dokumentasi IVAA (Indonesian Visual Art Archive) mengenai Sudjojono. Perlu diketahui, dalam sejarahnya, Bandara Kemayoran merupakan salah satu situs bersejarah panjang bagi dunia penerbangan Indonesia. Bandara tersebut pernah tercatat sebagai salah satu pintu gerbang penerbangan nasional jalur udara pertama di Jakarta.

Tidak luput pula dalam catatan sejarah, peristiwa, maupun kejadian dimasa itu, di dapatkan beberapa karya seni yang pernah menghiasi ruang demi ruang dan telah menghiasi ruangan bandar udara tersebut. Relief tersebut terletak di eks Bandar Udara Kemayoran, satu lahan dengan Kantor Pusat Pengelola Komplek Kemayoran (PPKK). Berseberangan pula dengan Mall Mega Glodok Kemayoran (MGK).

Pembangunan Lapangan terbang Kemayoran ini menuliskan sejarah bahwasanya seniman juga turut berperan andil menunjukan semangat nasionalisnya yang tinggi beserta para tokoh-tokoh Indonesia lainnya. Bung Karno yang kala itu merupakan tokoh yang sangat berpengaruh bagi bangsa Indonesia, dengan bangganya ingin mempersembahkan keistimewaan Indonesia di mata dunia dengan sebuah relief yang dirancang pada dinding ruang tunggu VIP, sehingga para tamu yang datang dari luar negeri dapat melihat keistimewaan Indonesia melalui dinding relief pada bandara tersebut.

Dahulu, pada zaman Indonesia masih belum merdeka, kawasan Kemayoran sudah menjadi salah satu area padat yang berada di jantung kota Batavia (Jakarta). Infrastuktur Kemayoran yang mempunyai lahan berpotensi dijadikan sebuah prasarana untuk menunjang pembangunan yang ada di Indonesia, terutama wilayah ibu kota Jakarta. Kemayoran merupakan salah satu kawasan yang berada di Jakarta bagian pusat. Kini kawasan tersebut menjadi sangat padat dengan ditumbuhinya 
gedung-gedung yang menjulang tinggi, apartemen mewah, dan menjadi kawasan yang dipenuhi dengan gedung perkantoran. Melalui data dari Pusat Pengelolaan Komplek Kemayoran (PPKK), Kemayoran mempunyai lahan-lahan berpotensi untuk dikembangkan. Salah satunya ialah lahan yang ada di area eks bandara Kemayoran yang luasanya kurang lebih sekitar 454 hektar. Gedung-gedung dan perkantoran yang berdiri diatas lahan eks bandara Kemayoran ini diantaranya adalah Mall Mega Glodok Kemayoran, Kantor Jasindo, Gedung Kejaksaan Tinggi Jakarta Pusat, Kantor PPKK, dan beberapa apartemen dengan tinggi menjulang.

Meskipun saat ini Kemayoran mengalami perkembangan yang sangat signifikan, tetapi masih tertinggal beberapa warisan budaya yang menghiasi jantung ibu kota ini. Ada tiga relief yang masih terukir dengan indah dan menghiasi salah satu gedung lapangan terbang pertama di Indonesia ini. Menara Kontrol ATC (Airport Traffic Control Tower) juga merupakan bangunan bersejarah yang sangat lekat dengan kawasan Kemayoran. Semenjak kawasan Kemayoran ini memulai sejarahnya dengan pembangunan bandar udara pertama di Batavia (Jakarta), bahkan di Indonesia, Kemayoran menjadi salah satu kawasan yang sering didatangi oleh para tokoh-tokoh penting dalam negeri ataupun mancanegara.

Kembali kepada pembahasan penelitian mengenai relief yang ada di eks Bandara Kemayoran, penulis mencoba untuk berpartisipasi terjun langsung ke lokasi penelitian. Membutuhkan waktu sekitar 20 menit apabila menggunakan kendaraan umum dari salah satu stasiun yang ada di wilayah Jakarta Pusat, yaitu Stasiun Juanda.

Lantai dan anak tangga yang basah membawa penulis menuju lantai dua ruang tunggu VIP yang berkilauan oleh genangan bocoran air hujan. Sepasang relief beton yang berhadapan di lantai satu sama merananya, seperti berdebu dan beberapa dihinggapi oleh sarang laba-laba. Beberapa bagian relief rancangan tiga seniman kondang Indonesia pada masa itu, S Sudjojono, Harijadi Sumadidjaja, dan Surono, bahkan ada yang hilang bagiannya.

Tidak dapat dipungkiri, bahwa di tempat yang memiliki sejarah panjang bagi penerbangan Indonesia itu, berdiri relief beton modern pertama di Indonesia. Relief tersebut merupakan sebuah karya seni yang dibuat oleh para seniman Indonesia antara lain Sindoesoedarsono Soedjojono, Harijadi Sumodidjojo, dan Surono serta para murid-muridnya pada tahun 1957 atas permintaan Presiden Soekarno pada saat itu. Relief tersebut terpajang di sebuah ruangan VIP Bandara Kemayoran dimana 
proses pengerjaannya dilakukan dengan teknik pahatan dalam. Ada rasa terpukau sekaligus perasaan haru ketika mengetahui bahwa dibalik keindahan dan keistimewaan penciptaan relief tersebut, tersimpan banyak sejarah dan sebuah narasi yang seakan berbicara kepada setiap orang yang memandangnya.

Keindahannya terasa ganjil di tengah segala kemuraman ruang tunggu itu. Cerita tentang keseharian Indonesia ada di sana, orang membajak sawah, nelayan mengarungi samudra, tifa, rebab dan gamelan, binatang mitologi, ragam buah dan hasil bumi, eloknya bentang alam Nusantara. Di sudut kiri bawah, terukir dua penanda, 'Seniman Indonesia Muda' dan 'Jogja 1957'. (Lihat Aryo Wisanggeni, Artikel Kompas: Kemayoran, Tintin, dan Kambing Piaraan, (Januari, 2015), p. 1, diakses pada 10 Agustus 2017 pukul 00.07 WIB)

Relief yang dibuat oleh para Seniman Indonesia Muda tersebut bertemakan tentang kekayaan yang dimiliki Indonesia. Sudjojono membuat relief dengan panjang perkiraan kurang lebih 30 meter dan tinggi 3 meter yang menggambarkan Manusia Indonesia yang sedang membangun dan bekerja di berbagai bidang. Harijadi S membuat relief dengan panjang perkiraan 10 meter dan tinggi 3 meter yang menggambarkan tentang keanekaragaman Flora dan fauna yang ada di Nusantara. Sementara itu, Surono membuat relief dengan panjang kurang lebih 13 meter dan panjang 3 meter yang menggambarkan sebuah legenda Sangkuriang.

Pada kesempatan penelitian tugas akhir ini, penulis mencoba fokus kepada salah satu relief dengan judul 'Manusia Indonesia' karya dari seniman Sudjojono. Relief 'Manusia Indonesia' tersebut memiliki dua panel dengan total ukurannya kurang lebih 30 meter dan tinggi 10 meter. Pada relief tersebut digambarkan kehidupan masyarakat Indonesia yang sedang mengerjakan bebagai aktivitas dengan tubuh yang kekar dan para pekerja yang mengerjakan berbagai pekerjaan. Pakaian mereka dibuat secara sederhana. Alas kaki yang dikenakan pun juga merupakan alas kaki pada jaman dahulu. Berbentuk sederhana dan berbahan dasar kayu seperti bentuk bakiak pada umumnya. Para pekerja yang tergambar pada sosok tersebut digambarkan dengan bertubuh pendek, namun kekar layaknya pekerja-pekerja Indonesia kala itu. Para perempuan lain juga digambarkan dengan menggunakan pakaian tradisional kebaya dan kain jarit yang biasa dikenalkan pada masa pra dan paska kemerdekaan Indonesia. 


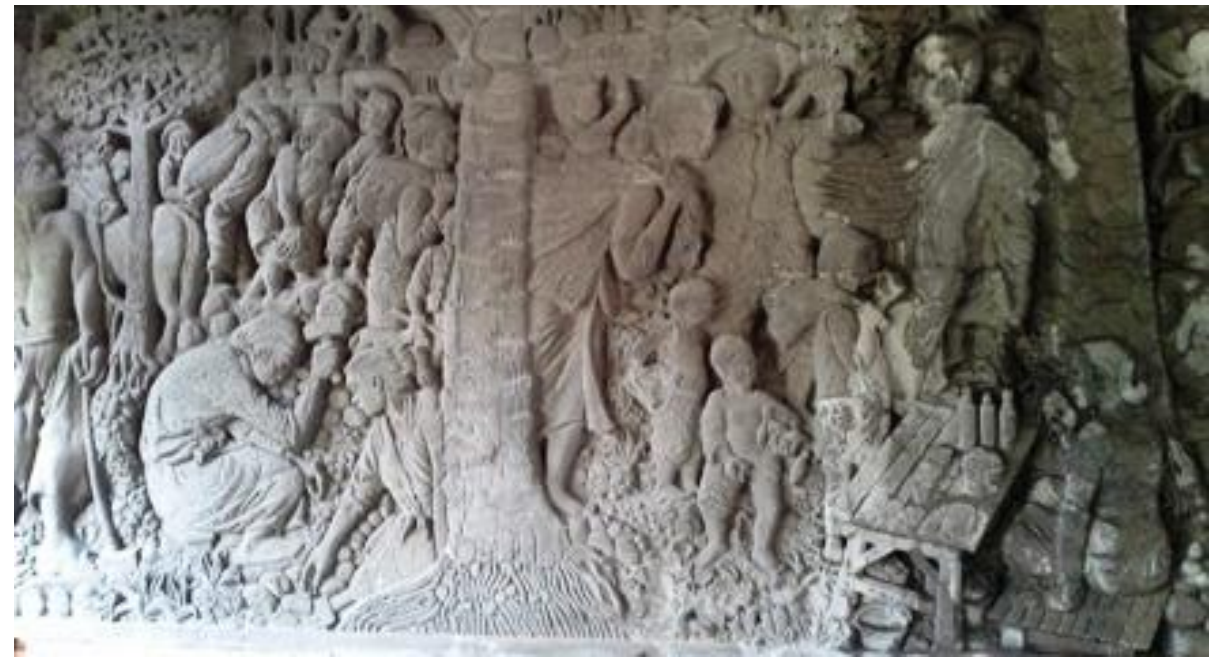

Gambar 1. Panel pertama Relief ‘Manusia Indonesia' karya Sudjojono di Ruang Tunggu VIP lantai dua eks Bandara Kemayoran, Jakarta Pusat

(Sumber: https://sgimage.detik.net.id/content/2013/07/15/10/reliefmanusial.jpg , diakses pada 11 Agustus 2017, pukul 18.10 WIB)

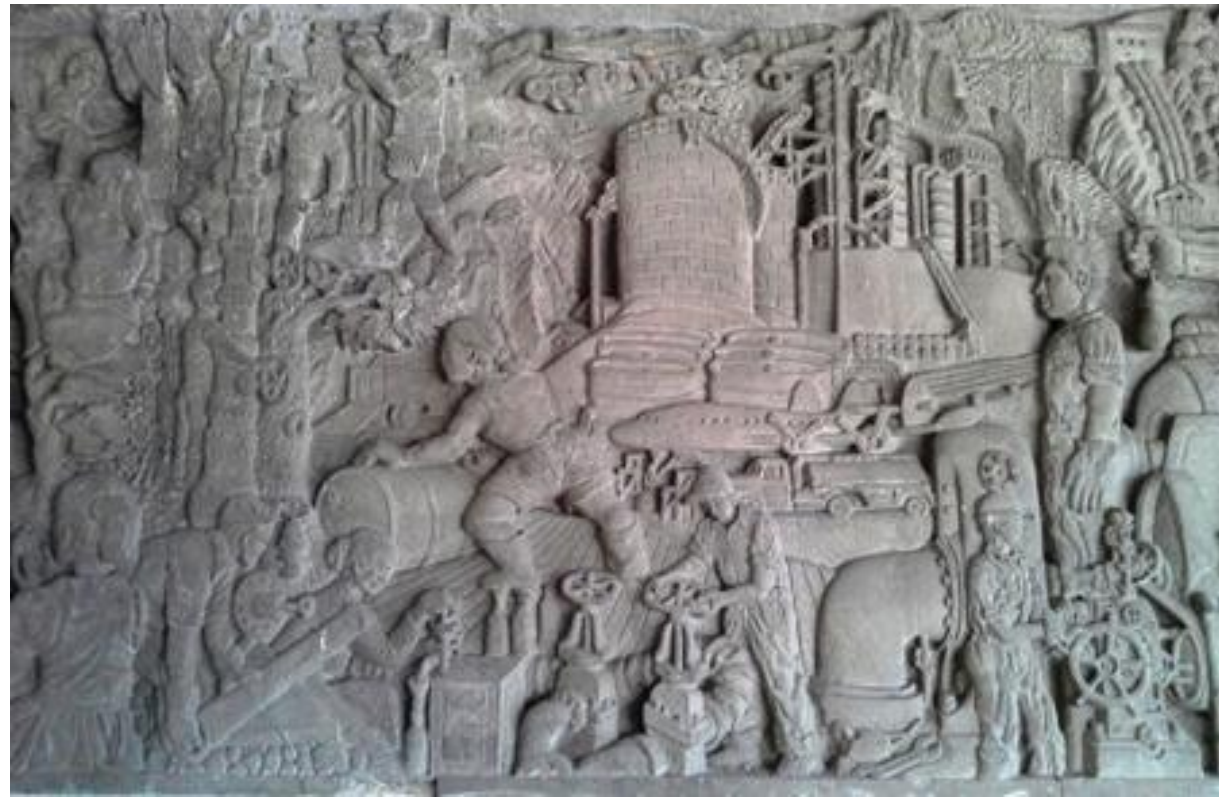

Gambar 2. Panel kedua Relief 'Manusia Indonesia' karya Sudjojono di Ruang Tunggu VIP lantai dua, Eks Bandara Kemayoran, Jakarta Pusat. (Sumber: http://news.detik.com/berita/2302576/ssstada-relief-cantik-dan-bersejarah-di-gedung-eks-bandara-kemayoran, diakses pada 11 Agustus 2017, pukul 18.08WIB)

Jika kita berjalan hendak menuruni tangga, maka akan terlihat pula sesosok figur wanita dengan pakaian langsung dengan stelan rok pada zaman dulu. Menurut penuturan anak pertama dari Sudjojono, Tedjabayu Sudjojono, sosok figur tersebut adalah sosok dari seorang Mia Bustam yang hendak digambarkan Sudjojono sebagai bukti cintanya kepada istrinya. Sosok Mia Bustam merupakan wanita yang ada pada sketsa relief 'Manusia Indonesia' tersebut, namun ada kisah lain dibalik gambar sesosok wanita itu karena banyak sumber yang juga menyatakan bahwa 
sosok perempuan tersebut adalah sosok dari Rose Pandanwangi yang menjadi istri kedua dari Sudjojono sendiri.

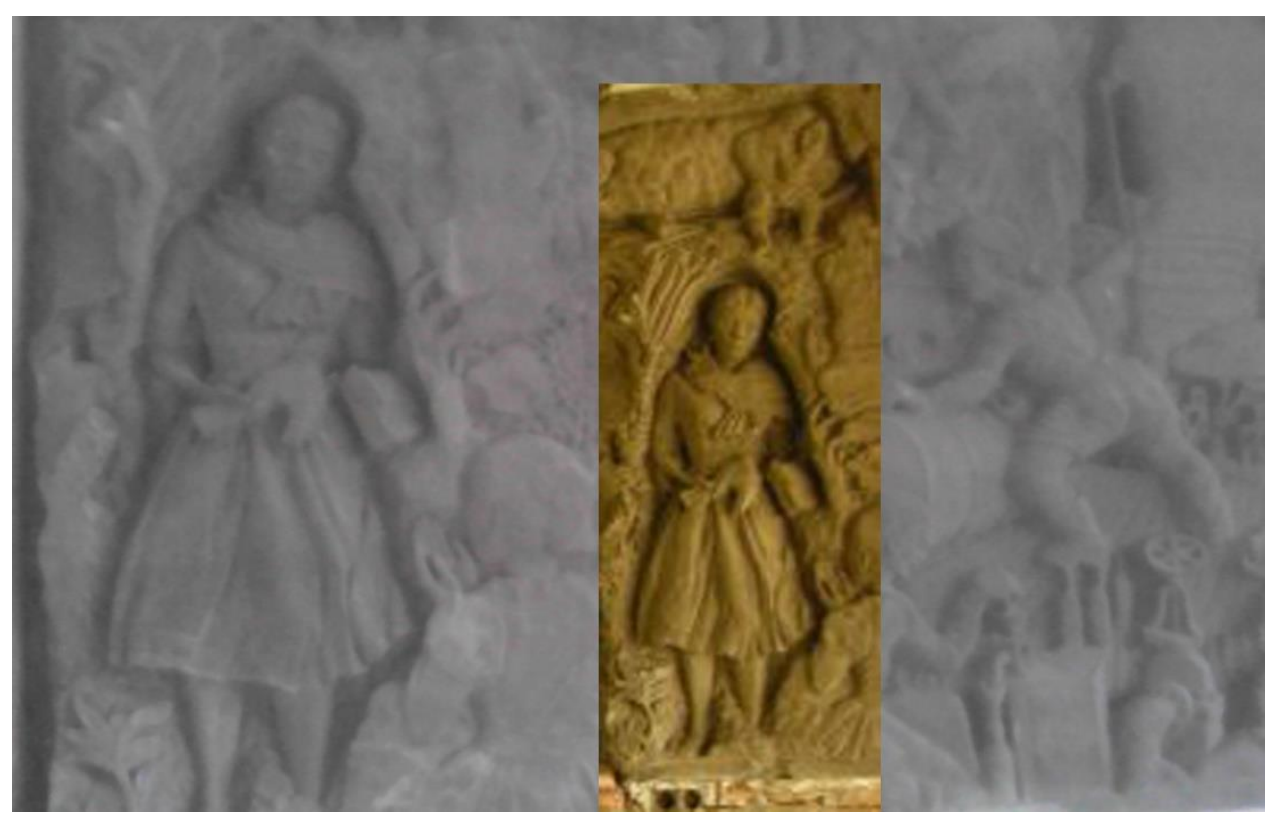

Gambar 3. Sosok figur perempuan pada panel kedua Relief 'Manusia Indonesia' karya Sudjojono di Ruang Tunggu VIP lantai dua, Eks Bandara Kemayoran, Jakarta Pusat. (Foto: Julia Dwi Yanti, 2016)

Ada beberapa bagian relief yang dipotong ketika gedung direnovasi, salah satunya adalah relief 'Manusia Indonesia' karya Sudjojono ini. Kondisi terkini ketika penulis mengunjunginya, salah satu panel pada bagian relief Manusia Indonesia tersebut berlubang dan retak dibagian tepi. Awalnya relief ini dibuat satu panel saja, namun dikarenakan keperluan renovasi, maka dibuat atau dipotong menjadi dua bagian.

Panel pertama terletak dibagian sisi kiri apabila kita menghadapnya. Berdasarkan bentuk figur, Sudjojono menggambarkan rakyat yang sedang bekerja. Beberapa pria digambarkan bertubuh kekar seperti pekerja pada masanya. Ada salah satu pekerja yang digambarkan dengan figur Sudjojono sendiri. Beberapa figur perempuan juga terlihat sedang menggendong anak dengan selendang atau sejenis kain yang biasa digunakan masyarakat Indonesia untuk menggendong pada umumnya. Selain figur dan penggambaran aktivitas masyarakat Indonesia, pada panel pertama tersebut terlihat sebuah pahatan yang membentuk sebuah perahu berlayar dan simbolisasi yang menggambarkan perairan yang luas. Pohon-pohon 
lokal seperti pohon kelapa, pohon pisang, dan pepaya juga terlihat sebagai ciri khas Negara Indonesia.

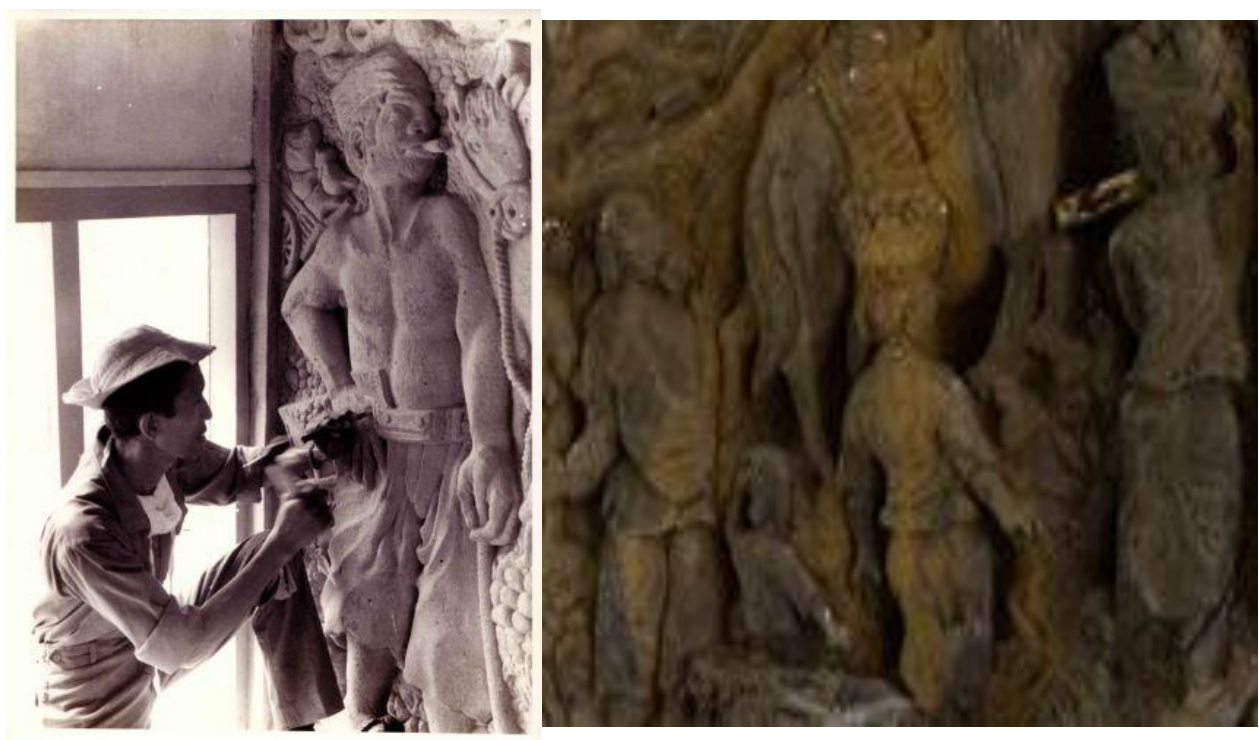

Gambar 4. Sosok kekar figur manusia Indonesia dan kearifan lokal pada relief 'Manusia Indonesia' karya Sudjojono di lantai dua Ruang Tunggu VIP Eks Bandara Kemayoran, Jakarta Pusat. (Sumber: http://archive.ivaa-online.org/khazanahs/detail/2211 , diakses pada 10 Agustus 2017, pukul 00:37 WIB)

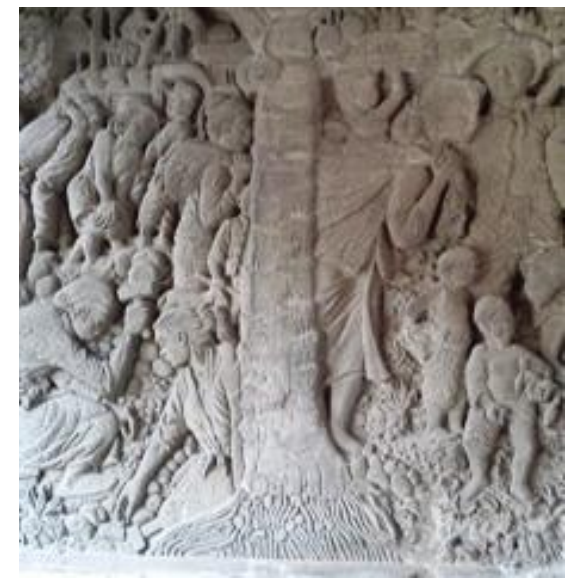

Gambar 5. Pohon papaya dan kelapa sebagai latar pada Relief 'Manusia Indonesia' karya Sudjojono di lantai dua Ruang Tunggu VIP Eks Bandara Kemayoran, Jakarta Pusat. (Sumber: http://archive.ivaa-online.org/khazanahs/detail/2211 , diakses pada 10 Agustus 2017, pukul 00:44 WIB)

Selanjutnya penulis akan membahas mengenai figur pada panel kedua relief 'Manusia Indonesia' karya Sudjojono. Dalam rangkaian panel kedua tersebut terangkai beberapa adegan dimana para pekerja sedang mengerjakan sesuatu pekerjaan pembangunan. Para lelaki digambarkan bertubuh kekar sedang mengambil hasil bumi dari Indonesia. Ada pula adegan dimana para pekerja bersemangat mengeruk pasir hasil kekayaan Indonesia. Ada sesosok wanita yang digambarkan sebagai perhatian disana karena porsi dari tubuhnya yang besar. 


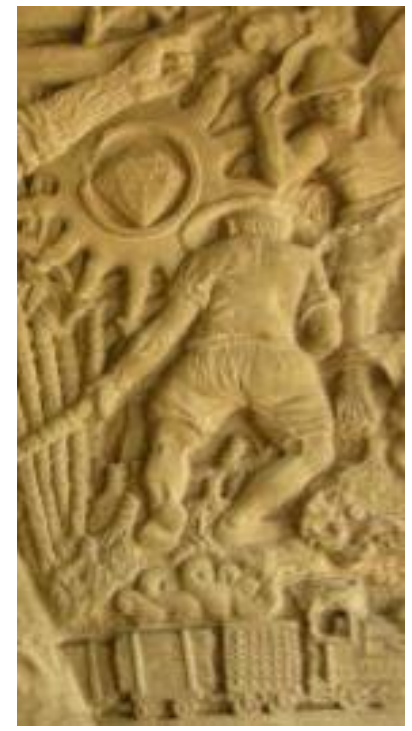

Gambar 6. Figur para pekerja yang sedang mengeruk pasir dan hasil tambang pada Relief 'Manusia Indonesia' karya Sudjojono di lantai dua Ruang Tunggu VIP Eks Bandara Kemayoran, Jakarta Pusat. (Sumber: http://archive.ivaa-

online.org/khazanahs/detail/2211, diakses pada 10 Agustus 2017, pukul 00:55 WIB)

Menurut penuturan Tedja Bayu Sudjojono, sosok perempuan tersebut adalah Ibundanya yaitu sosok dari seorang Mia Bustam. Namun menurut penuturan beberapa sumber, sosok perempuan tersebut adalah Rose Pandanwangi yang menjadi isteri keduanya setelah berpisah dengan Mia Bustam. Pembahasan figur wanita yang terdapat pada panel kedua relief 'Manusia Indonesia' karya Sudjojono dapat dikaitkan dengan simbolik dari sebuah narasi Ibu Pertiwi yaitu bumi Nusantara (Indonesia) (Lihat gambar 3).

Apabila diamati dengan seksama, terdapat simbol matahari pada panel kedua relief 'Manusia Indonesia' tersebut. Penulis menganalisis pahatan matahari disana yaitu sebagai simbol bahwasanya Negara Indonesia mempunyai masa depan yang cerah dan hasil kekayaan alam yang berlimpah.

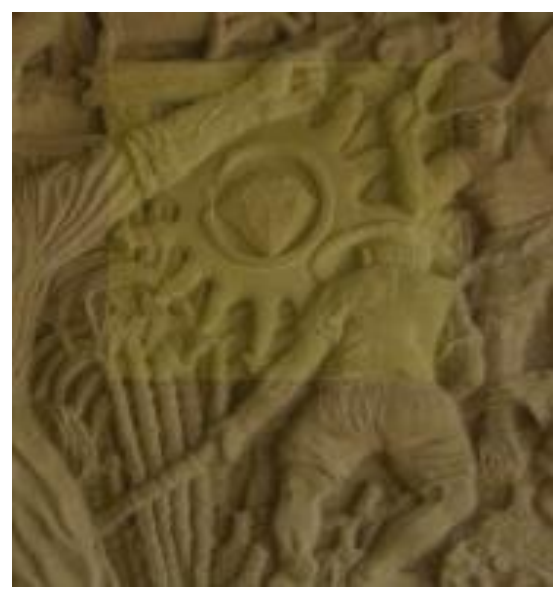

Gambar 7. Simbol matahari dan berlian pada Relief 'Manusia Indonesia' karya Sudjojono di lantai dua Ruang Tunggu VIP Eks Bandara Kemayoran, Jakarta Pusat. (Sumber: http://archive.ivaaonline.org/khazanahs/detail/2211, diakses pada 10 Agustus 2017, pukul 01:16 WIB) 


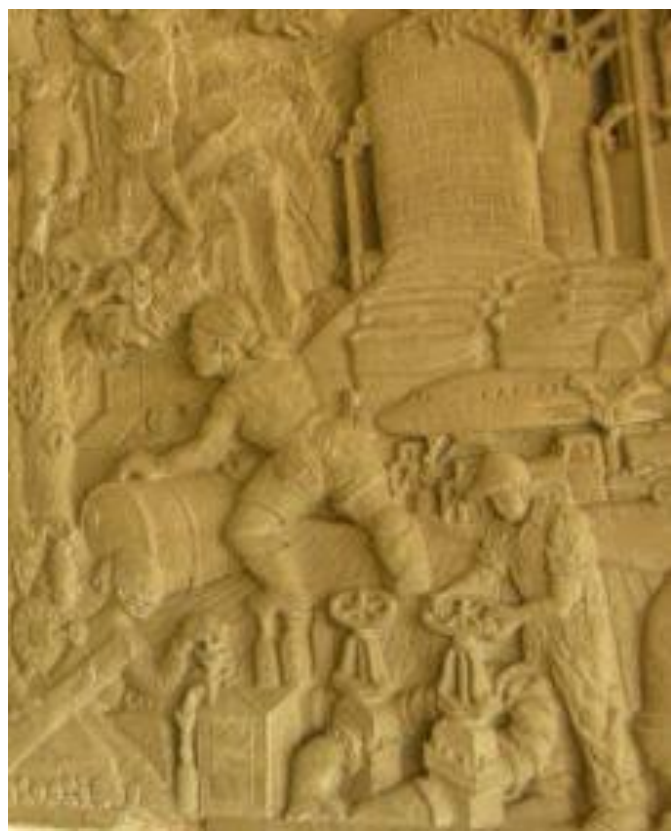

Gambar 8. Figur para pekerja yang sedang mengambil hasil tambang pada Relief 'Manusia Indonesia' karya Sudjojono di lantai dua Ruang Tunggu VIP Eks Bandara Kemayoran, Jakarta Pusat. (Sumber: http://archive.ivaaonline.org/khazanahs/detail/2211, diakses pada 10 Agustus 2017, pukul 00:55 WIB)

Latar yang dibangun dalam panel kedua 'Manusia Indonesia' karya Sudjojono tersebut berlatar belakang pemandangan Indonesia dan limpahan hasil kekayaan yang ada di Indonesia. Pemandangan yang serupa juga terlihat ketika pekerjaan tersebut dilakukan oleh para perempuan.

Perjalanan kisah Bandar Udara Kemayoran yang terjadi dari tahun ke tahun serta terjadinya perubahan zaman membuat pemukiman di Kemayoran pun semakin padat. Pemerintah akhirnya membangun Bandar Udara Internasional SoekarnoHatta di Cengkareng. Pada tanggal 1 Oktober 1984, maskapai Merpati mulai memindahkan penerbangan dari Kemayoran, Jakarta Pusat ke Bandar Udara Soekarno-Hatta, mengawali penutupan Bandar Udara Internasional Kemayoran. (Lihat Aryo Wisanggeni, Artikel Kompas: Kemayoran, Tintin, dan Kambing Piaraan, (Januari, 2015), p. 1, diakses pada 10 Agustus 2017 pukul 01.40. WIB)

Melalui beberapa pertimbangan menyangkut tidak bisanya lagi lapangan terbang ini difungsikan sebagaimana mestinya, maka penerbangan dialihkan ke bandara Halim Perdana Kusuma di Cililitan. Itulah akhir dari berjayanya Kemayoran sebagai kawasan yang terkenal sebagai area landasan pacu udara.

\section{Narasi Simbolik Relief 'Manusia Indonesia' karya Sudjojono}

Narasi dalam karya rupa bertolak dari pemahaman dasar naratif yang ada di dalam sebuah karya sastra atau puisi. Kita baru bisa memeriksa struktur naratif dalam karya rupa secara ideal apabila unsur-unsur dalam cerita dapat terpenuhi. Karya rupa, bagaimanapun juga merupakan genre yang sama 
sekali berbeda dengan karya sastra. Karya rupa tidak bercerita secara verbal sebagaimana halnya berseni dalam sastra. Oleh sebab itu, acuan bagi karya rupa naratif bersifat spesifik, berbeda dengan acuan bagi narasi dalam sastra.

Pembahasan mengenai sebuah narasi dengan simbol-simbol yang ada pada suatu karya relief tentunya tak luput dari pengertian relief itu sendiri. Menurut kamus besar bahasa Indonesia, Pengertian relief adalah pahatan yang menampilkan perbedaan bentuk dan gambar dari permukaan rata disekitarnya. Dapat diartikan juga sebagai gambar timbul pada candi dan sebagainya, serta perbedaan ketinggian pada bagaian permukaan bumi. Relief adalah seni pahat dan ukiran tiga dimensi yang biasanya dibuat diatas batu maupun beton. Relief juga merupakan ukiran yang berdiri sendiri, maupun sebagai bagian dari panel relief yang lain, membentuk suatu cerita atau narasi dari suatu peristiwa.

Melihat dari segi fungsinya, fungsi relief secara universal adalah untuk menceritakan semua yang telah terjadi di masa yang telah terjadi kala itu, untuk mengilustrasikan kehidupan masyarakat pada zaman dahulu dan sebagai bukti sejarah dizaman selanjutnya, serta berfungsi sebagai penanda kebudayaan, agama dan lain-lain. Sekilas mengetahui tentang sejarah berdirinya Bandar Udara Kemayoran sampai kepada pengantar mengenai relief diatas, penelitian kali ini akan menjurus kepada salah satu karya, yaitu karya relief Sudjojono yang berjudul "Manusia Indonesia".

Pada tahap melihat dan memaknai sebuah narasi yang ada pada relief Manusia Indonesia karya Sudjojono, penulis menggunakan empat tahapan yang biasa digunakan pada saat melakukan sebuah kritik seni. Tahapan yang pertama ialah deskripsi. Menurut pengertiannya, deskripsi merupakan tahapan awal dalam kritik untuk menemukan, mencatat dan mendeskripsikan segala sesuatu yang dilihat apa adanya dan tidak berusaha melakukan analisis atau mengambil kesimpulan. Agar dapat mendeskripsikan dengan baik, kita harus mengetahui istilah-istilah teknis yang umum digunakan dalam dunia seni rupa. Hal tersebut perlu diperhatikan karena apabila tanpa didasari pengetahuan tersebut, niscaya akan sulit untuk mendeskripsikan fenomena karya yang dilihat.

Maka melalui deskripsi karya, penulis menemukan beberapa gambaran yang akan diungkapkan. Narasi simbolik yang penulis amati berdasarkan 
gambar yang diambil melalui alat bantu seperti kamera. Relief ini diperkirakan memiliki panjang 10 meter dengan tinggi 3 meter pada setiap panelnya.

Bidang pertama relief berjudul "Manusia Indonesia" yang dirancang oleh Sudjojono seakan menggambarkan rakyat yang sedang bekerja. Beberapa pria yang digambarkan bertubuh kekar seperti pekerja pada umumnya namun dibuat pendek. Sosok atau figur gambaran perempuan yang terlihat juga ditonjolkan dengan karakter kearifan lokal masyarakat Indonesia, yaitu dengan menggunakan sanggul kepala dan baju kebaya serta pakaian khas Indonesia pada umumnya kala itu. Ukiran yang terdapat pada setiap panel terlihat mendetail dan menarik. Ciri khas kebiasaan atau adat masyarakat Indonesia juga sangat kental terlihat yaitu dengan adanya adegan seorang ibu yang menggendong anaknya menggunakan kain jarik, bahkan ada yang sampai membawa barang seperti hasil bumi Indonesia diatas kepalanya. Tumbuhan dan tanaman khas di Indonesia juga ditampilkan pada panel pertama, semuanya dibuat dengan bentuk figuratif. (lihat gambar 4 dan 5).

Selain itu, tampak pula sebuah bentuk perahu kapal seakan sang seniman ingin menyampaikan bahwa Indonesia merupakan sebuah negara maritim yang kekayaannya lautannya tak tertandingi oleh negara manapun.

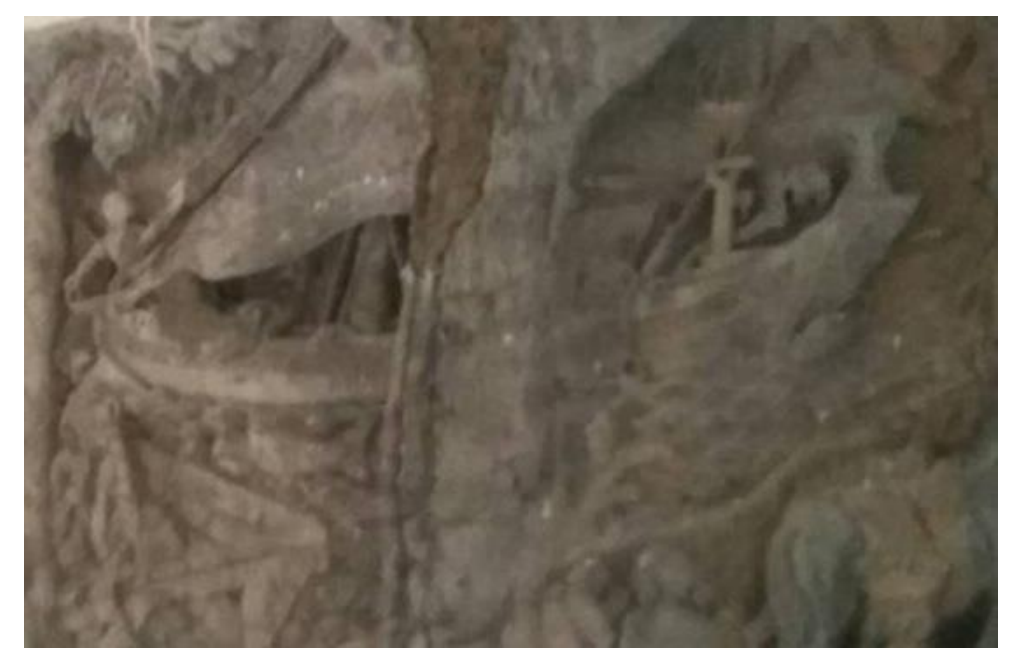

Gambar 9. Ukiran perahu dan hewan lokal pada Relief 'Manusia Indonesia' karya Sudjojono di lantai dua Ruang Tunggu VIP Eks Bandara Kemayoran, Jakarta Pusat. (Foto: Julia Dwi Yanti 2016)

Bidang kedua relief "Manusia Indonesia" karya Sudjojono juga masih bercerita mengenai semangat masyarakat Indonesia yang bahu-membahu 
saling membantu dalam melaksanakan suatu kegiatan. Disana terlihat para lelaki yang sedang melakukan berbagai pekerjaan, diantaranya menggiling hasil pertanian seperti beras, jagung, tebu, dan mengumpulkan hasil perkebunan lainnya. Berbagai hasil kekayaan Indonesia seperti emas, tembaga, berlian dan sebagainya yang diambil dari perut bumi nusantara juga digambarkan dalam panel kedua relief tersebut (lihat gambar 6, 7 dan 8).

\section{SIMPULAN}

Berdasarkan penyajian data dan analisis yang telah dipaparkan pada pembahasan mengenai Narasi Simbolik Relief 'Manusia Indonesia' karya Sudjojono di Eks Bandara Kemayoran, maka dapat ditarik kesimpulan sebagai berikut:

1. Gambar relief dibuat atas permintaan Soekarno pada tahun 1957. Relief dikerjakan langsung oleh tiga seniman ternama Indonesia, yaitu Sindoesoedarsono Soedjojono, Harijadi Sumodidjojo, dan Surono. Relief beton tersebut menjadi buah karya yang dibanggakan karena dibuat khusus untuk menyambut para tamu negara pada masa itu.

2. Menurut Santu Wirono yang juga pelukis putra dari Harijadi S. analisis sederhananya, relief beton ini merupakan relief modern pertama di Indonesia mengingat, pertama, relief tidak terikat pada tradisi relief di Jawa, Bali dan daerah lain yang bernafaskan agama atau kepercayaan.

3. Pada relief 'Manusia Indonesia' karya Sudjojono diungkap ide mengenai kebudayaan dan kearifan lokal masyarakat Indonesia. Sudjojono ingin menonjolkan bagaimana citra Indonesia di mata dunia. Dengan latar belakang dan pemahaman kerakyatan yang kuat, Sudjojono berfikir tentang bagaimana cara untuk menghebatkan seniman-seniman kecil yang memang mereka itu adalah rakyat dalam arti yang sebenarnya. Mengangkat citra seniman yang pada dasarnya adalah rakyat dari kalangan bawah, bukan dari bangsawan yang kehidupannya sudah terjamin dari zaman prakemerdekaan,

4. Kisah tentang bagaimana kehidupan masyarakat Indonesia sebelum terbentuknya Republik Indonesia. Pemikiran terhadap kebanggaan dalam mengangkat rakyat jelata yang semestinya menjadi raja di negaranya sendiri. Masyarakat Indonesia yang pada ahkirnya merdeka kala itu, dengan 
bangganya dapat mempertunjukkan kepada dunia bahwa pada Bangsa ini memiliki kesempurnaan alam, budaya dan tradisinya yang melimpah, sebagaimana cerita terstruktur pada cerita yang dibuat di relief karya Seniman Indonesia Muda pada awal era kemerdekaan Republik Indonesia.

5. Narasi yang ada serta nilai dari makna simbolik yang tertera dalam relief tersebut sebenarnya dapat menjadi rangkaian cerita dari sejarah representasi kondisi masyarakat Indonesia kala itu

\section{DAFTAR PUSTAKA}

Berger, Arthur Asa, (2000). Tanda-Tanda dalam Kebudayaan Kontemporer: Yogyakarta: Tiara Wacana Yogya.

Bustam, Mia. (2006), Sudjojono dan Aku: Yogyakarta: Pustaka Utan Kayu.

Danesi, Marcel. (2010), "Pesan, Tanda dan Makna: Buku Teks Dasar Mengenai Semiotika dan Teori Komunikasi”: Yogyakarta: Jalasutra.

Dwi Marianto, M. (2015), Art and Levitation: Seni dalam Cakrawala Quantum. Yogyakarta: Penerbit Cahaya.

Dyastriningrum. (2009), Antropologi Kelas XII: Jakarta: Pusat Perbukuan, Departemen Pendidikan Nasional.

Hafiz, Ugeng T. Moetidjo. (2007), Seni Lukis Indonesia Tidak Ada: Jakarta: Dewan Kesenian Jakarta.

Hoed, Benny H. (2011), Semiotik dan Dinamika Sosial Budaya: Depok: Komunitas Bambu.

Kartika, Dharshono Sony. (2007), Kritik Seni: Bandung: Rekayasa Sains Bandung.

Margono, S. (2015), Metodelogi Penelitian Pendidikan: Jakarta: Rineka Cipta.

Rosidi, Ajip. (2000), Pelukis S. Sudjojono: Yogyakarta.

Sanyoto, Sadjiman Ebdi. (2010), Nirmana, Elemen-elemen Seni dan Desain. Yogyakarta: Jalasutra.

Setiawan, Hersri. (2006), Sudjojono dan Aku: Yogyakarta: Pustaka Utan Kayu.

Soedjatmoko. (2004), Kebudayaan Sosialis: Jakarta: Melibas.

Widyamartaya, A. (1990), Seni Menuangkan Gagasan. Yogyakarta: Kanisius. 
Yuliman, Sanento. (1976), Seni Lukis Indonesia Baru-Sebuah Pengantar. Jakarta: Dewan Kesenian Jakarta.

\section{Website}

Alesander, Hilda, (Oktober, 2013) "Terancam Dihancurkan, Selamatkan Menara Kemayoran”, artikel Kompas, diakses pada 10 Agustus 2017 pukul 01.40. WIB.

Ghozim, (Oktober 2011), "Seni Bagian dari Budaya" diakses pada 7 Agustus 2017 pukul 22.50 WIB at URL: http://gozhimcentre.blogspot.co.id/2011/10/seni-bagian-dari-budaya.html

https://jeashafidzh.wordpress.com/2016/08/27/mengkaji-bahasa-rupa-melaluianalisis-semiotika-umberto-eco/, diakses pada 27 Agustus 2016 pukul 07.45 WIB.

http://news.detik.com/berita/2302576/ssst-ada-relief-cantik-dan-bersejarah-digedung-eks-bandara-kemayoran diakses 11Agustus 2017 pukul 18.08

http://properti.kompas.com/read/2013/10/16/0816399/Terancam.Dihancurkan.Sel amatkan.Menara.Kemayoran. diakses 4 Desember 2016 jam 11.06

https://sgimage.detik.net.id/content/2013/07/15/10/reliefmanusia1.jpg, diakses pada 11Agustus 2017 pukul 18.10 WIB

Kawashima, Van Damian, (November, 2015) "Makalah Seni Rupa Manusia \& Kebudayaan, Pengertian Seni, Konsep Keindahanp" diakses pada 9 Agustus 2017 jam 18.50 at URL:https://www.slideshare.net/ivancyberkids/makalahseni-rupa-manusia-kebudayaan-pengertian-seni-konsep-keindahan

Kusumastuti, Eny. (2013), "Jurnal Filsafat Ilmu dalam Perspektif Estetika" diakses pada 7 Agustus 2017 jam 23.02 WIBat URL:

http://www.academia.edu/9723312/filsafatilmudalamperspektifestetika

Laili, Amin Laili, (Juni, 2015), "Kapitalisme di Eks Bandara Kemayoran”, artikel Kompas, diakses pada 7 Agustus 2017 pukul 23.01WIB.

Rosyida, Lutfi Khoiri. (Juni, 2015) "Estetika dan Filsafat Keindahan", artikel Kompasiana, diakses pada 9 Agustus 2017, jam 01.25 WIB at URL: http://www.kompasiana.com/www.fhepooh.com/estetika-dan-filsafatkeindahan_550ab0bc813311cf14b1e199

Tedi Sutardi, (Juni, 2001) artikel "Antropologi: Mengungkap Keberagaman Budaya".

Sumbo Tinarbuko, (Januari, 2003) "Jurnal Semiotika Analisis Tanda pada Karya Desain Komunikasi Visual” Vol. 5, No. 1, ISI Yogyakarta diakses tanggal 5 Agustus 2017 at URL: http://nirmana.petra.ac.id/index.php/dkv/article/viewFile/16093/16085 
JOURNAL of

CONTEMPORARY INDONESIAN ART

Web Pusat Pengelolaan Komplek Kemayoran, (Juni, 2016), "Warisan Eks

Bandara Internasional Kemayoran" diakses pada 10 Agustus 2017 pukul 02.23 WIB.

Wisanggeni, Aryo, (Januari, 2015), “Kemayoran, Tintin, dan Kambing Piaraan", artikel Kompas, diakses pada 9 Agustus 2017 pukul 17.36 WIB. 